\title{
Existing Emission Calculation Methods Applied to Monitoring, Reporting and Verification (MRV) on Board
}

\section{Postojeće metode izračuna emisije koje se primjenjuju na praćenje, izvješćivanje i verifikaciju (MRV) na brodu}

\author{
Marcella Castells-Sanabra \\ Universitat Politècnica de Catalunya (Barcelona·TECH) \\ Department of Nautical Science and Engineering, Spain \\ e-mail: marcella.castells@upc.edu \\ Jordi Torralbo \\ Universitat Politècnica de Catalunya (Barcelona·TECH) \\ Department of Nautical Science and Engineering, Spain \\ e-mail: jorge.torralbo@upc.edu
}

\section{Clara Borén}

Universitat Politècnica de Catalunya (Barcelona·TECH) Department of Nautical Science and Engineering, Spain e-mail: clara.boren@upc.edu

\author{
Ruurd van der Meer \\ Büro Blue/Green \\ The Netherlands \\ e-mail: info@burobluegreen.com
}

\author{
Santiago Ordás \\ Universitat Politècnica de Catalunya (Barcelona.TECH) \\ Department of Nautical Science and Engineering, Spain \\ e-mail: santiago.ordas@upc.edu
}

DOI 10.17818/NM/2020/2.9

UDK 504.7:656.61

Professional paper / Stručni rad

Paper accepted / Rukopis primljen: 15. 7. 2019

\section{Summary}

Monitoring, Reporting and Verification (MRV) of emissions on board has been proposed as a measure to reduce global greenhouse gas (GHG) emissions. The requirements for MRV are set by two legislative bodies, the European Union (EU-MRV) and the International Maritime Organization (IMO-DCS) and ships have to comply with them. However, current maritime practices do not permit the right implementation of MRV and best practices can only be developed after a certain time of experience. A solution could be the application of the different existing emission calculation methods on the phase of MRV where it is most useful. This contribution explores which method could be useful as maritime best practices and could meet the goals of EU-MRV and IMO-DCS. Eleven existing methods have been assessed by a set of questions based on key MRV elements found in literature. Methods have been classified within Theoretical Based Methods (TBM) and Ship Based Methods (SBM). TBM methods may not comply with the monitoring phase of MRV but could be feasible as alternative method when activity data from ships are extracted. On the other hand, SBM methods seem to be the most appropriates to comply with MRV specifications, but need more investments on board and therefore require best practices regarding the way of application. The assessed methods are already available, possibly suitable to be used for monitoring, and therefore applicable as early best practices, with the understanding that some of the methods are theoretical, based on assumptions, and often too general. Nevertheless, a different approach like the one presented in this contribution may be supportive in the understanding of MRV on board.

\section{Sažetak}

Praćenje, izvješćivanje i verifikacija (MRV) emisija na brodu predloženi su kao mjera za smanjenje globalne emisije stakleničkih plinova. Zahtjeve MRV-a postavila su dva zakonodavna tijela, Europska unija (EU-MRV) i Međunarodna pomorska organizacija (IMO-DCS), a brodovi ih moraju ispuniti. Međutim, trenutna pomorska praksa ne dopušta ispravnu provedbu MRV-a, a najbolje prakse mogu se razviti teknakon stečenog iskustva. Rješenje može bitiprimjena različitih postojećih metoda izračuna emisije u onoj fazi MRV-a gdje je to najkorisnije. Ovaj rad istražuje koja bi metoda mogla biti korisna kao najbolja pomorska praksa i koja bi mogla ispuniti ciljeve EU-MRV i IMODCS. Jedanaest postojećih metoda bilo je procijenjeno uz pomoć skupa pitanja temeljenih na ključnim MRV elementima koji se nalaze u literaturi. Metode su podijeljene na Teorijske metode (TBM) i Brodske metode (SBM). TBM metode možda nisu u skladu s fazom praćenja u sklopu MRV-a, ali mogu biti izvedive kao alternativna metoda kad se s brodova dobiju podaci o aktivnostima. $S$ druge strane, čini se da su SBM metode najprikladnije za udovoljavanje specifikacijama MRV-a, ali je potrebno više ulaganja na brodu i stoga su potrebne najbolje prakse u primjeni. Procijenjene metode su već dostupne, moguće ih je koristiti za praćenje, te se primjenjuju kao rane najbolje prakse, imajući na umu da su neke od metoda teorijske, temeljene na pretpostavkama i često preopćenite. Unatoč tome, drukčiji pristup poput onoga predstavljenog u ovom radu može pomoći u razumijevanju funkcioniranja MRV-a na brodu.

\section{KEY WORDS}

monitoring

reporting and Verification (MRV)

emission assessment

maritime best practices

\section{INTRODUCTION / Uvod}

Maritime transport is a contributor to global warming and air pollution. The total shipping fuel consumption increased from 291 to 298 million tonnes from 2013 to 2015, increasing the emissions over this period, including $\mathrm{CO}_{2}, \mathrm{CH}_{4}$, and $\mathrm{N}_{2} \mathrm{O}$ emissions [1]. Moreover, shipping is responsible for $15 \%$ and $13 \%$ of global $\mathrm{NO}_{x}$ and $\mathrm{SO}_{x}$ emissions respectively in 2012 [2]. Shipping global greenhouse gas (GHG) emissions are increasing despite improvements in operational efficiency for many ship 
types. Various measures and methods are proposed to reduce the environmental impact of shipping: (i) slow steaming [3, 4], (ii) the use of alternative fuels like hydrogen or Liquefied Natural Gas (LNG) [5] and (iii) technical and design optimizations [6, 7, 8]. Other measures like the obligatory Energy Efficiency Design Index (EEDI) - improving ship efficiency by ship design - and the voluntarily Energy Efficiency Operational Index (EEOI) improving efficiency by operational measures - are introduced to stimulate shipping to become more efficient [9].

[10] argue that effective energy management is incompatible with established shipping business practices. An energy efficiency gap is recognized due to the existence of barriers [11, 12]. Some examples of these hampering barriers are: (i) lack of reliable information about the reduction potential of efficiency measures, (ii) lack or a perceived lack of technical information, (iii) costs issues, (iv) organizational structures and (v) inconsistent legislation [11, 13, 14, 15]. Moreover, best practices related on energy consumption monitoring require real-time disaggregated data for each consumer (or at least the main consumers). In this sense, Monitoring, Reporting and Verification (MRV) emissions on board has been proposed as a measure to reduce GHG [16]. Therefore, the annual fuel consumption and/or carbon emissions of each individual ship needs to be reported to the legal authorities and the results are verified assessing if ships comply with the regulations or if some actions need to be taken in the future. The requirements for MRV are set by two legislative bodies, the European Union (EU-MRV) [17] and the International Maritime Organization (IMO-DCS, Data Collection Scheme) [18]. On one hand, annual reported emission data should be made transparent by making these publicly accessible proposing four methods for monitoring on board: (1) using bunker fuel delivery note (BDN), (2) bunker fuel tank monitoring, (3) Flow meters for applicable combustion processes and (4) Direct $\mathrm{CO}_{2}$ emissions measurements. On the other hand, the Marine Environmental Protection Committee (MEPC) of IMO agreed on a global MRV scheme and results obtained should be stored in the IMO Ship Fuel Oil Consumption Database and should be analysed and used as benchmark for new regulations. Table 1 shows the differences and similarities between both regulations.

Both regulations emphasize that the extra (administrative) burden on the crew should be as low as possible, prioritizing the use of the existing systems in monitoring to keep extra investments as low as possible. This is the reason why the European scheme proposes two methods that are already available for ships: the use of bunker delivery notes and fuel tank soundings; the other two methods require additional investments. However, shipping faces uncertainty about the way of monitoring: which parameters need to be measured and which data is required and how? Paradoxically, analogue problems arise around the implementation of MRV. [10] concludes that current maritime business practices do not permit the right implementation of MRV. What is required and how to implement and apply MRV on board ships?

Existing practices are not well developed and shipping has already to comply with both regulations being crucial to find suitable methods for MRV. The main objective of this paper is to assess the existing methods for inventorying ship emissions and to find best practices that will help the correct implementation of MRV. Therefore, this contribution is organized as follows: after the Introduction (Section 1), the key essentials of MRV (such as quality, uncertainty and confidence) are provided in Section 2. Section 3 (methods) presents an overview of the existing methods for calculating ship emissions (including the four proposed by EUMRV) and a set of MRV related questions. Section 4 shows the results after the assessment of these methods in order to conclude which of them are possibly suitable for MRV or useful for some phase of MRV. Finally, discussion and conclusions are highlighted in final sections (Section 5 and Section 6 respectively).

\section{MRV KEY ESSENTIALS LITERATURE / Osnove MRV-a u literaturi}

Emission reduction goals cannot be reached when a method for Monitoring, Reporting and Verification emissions does not meet the fundamental requirements. These fundamentals need to be clear before a method is assessed for its usefulness. [19] present a list of elements that should be included in an MRV scheme used

Table 1 Overview of the differences and similarities between EU-MRV and IMO-DCS Tablica 1. Pregled razlika i sličnosti između EU-MRV i IMO-DCS

\begin{tabular}{|c|c|c|}
\hline & EU-MRV & IMO-DCS \\
\hline \multirow{3}{*}{ Monitoring } & Ships 5,000 GT and above & Ships 5,000 GT and above \\
\hline & Voyages to/from EU port of calls & All voyages \\
\hline & EU Monitoring Plan & $\begin{array}{l}\text { Updated Ship Energy Efficiency Management } \\
\text { Plan (SEEMP) }\end{array}$ \\
\hline First monitoring period & 1 January 2018 & 1 January 2019 \\
\hline Exemptions & $\begin{array}{l}\text { Naval vessels, fish-catching/processing ships, } \\
\text { ships not propelled by mechanical means and } \\
\text { government ships used for non-commercial } \\
\text { purposes. }\end{array}$ & To be determined \\
\hline \multirow{4}{*}{ Parameters } & Fuel consumption (port/sea) & Fuel consumption \\
\hline & Transport work (based on actual cargo carried) & Distance \\
\hline & Distance & Time \\
\hline & Time & - \\
\hline Verification & Independent accredited verifiers (April 2019) & Flags/recognized organizations \\
\hline Reports to & European Commission & Flag State \\
\hline Certification & Document of Compliance (June 2019) & Statement of Compliance \\
\hline Publication & Distinctive public database & Anonymous public data \\
\hline
\end{tabular}

Source: EU-MRV [17] and IMO-DCS [18] 
by Environmental Protection Agency (EPA) in various emission programs. These elements are purely policy-related and are not directly relevant for the usefulness of a method for MRV on board, because the decisions are made on policy and legislative levels. The relevant elements under quality, uncertainty and confidence in MRV programs are summarized herein.

\subsection{Quality / Kvaliteta}

The quality of the application and outcome of an MRV program is an important issue. Quality assurance is essential for the confidence in the program and the integrity of the work done. Equipment performance standards, competency of personnel and strong auditing methods are included in good quality assurance [19]. The monitoring equipment needs to be trustworthy and reliable. Reliable monitoring needs skilled people who are involved in the monitoring process such as the monitoring operators and reporters and also auditors in the validation process. It is important that all actors/stakeholders do what is expected of them within the MRV scheme. Training and understanding is of vital importance. Therefore, a collaborative approach in the process is meaningful. There is a constant interaction among the legislating, executing, and controlling actors. Collaboration provides a better compliance rate, resource savings, understanding and a more productive relationship among the actors. [20] highlight the human role for the implementation of energy efficiency measures in the maritime domain. According [21] - as cited by [20] - many shipping companies do not possess the ability to address energy efficiency measures on a systematic base within their organisations. One of the main causes of this lack of ability is that shore operations and ship operations are often confronted instead of aligned in their way of working. This issue hampers the implementation of MRV on board. Quality is strongly related to the validity of MRV because it should improve the monitoring results.

\subsection{Uncertainty / Nedoumica}

Uncertainties are inherent to monitoring, caused by the lack of accuracy and precision in the measurement process [16]. Quality control and verification can be used to deal with the lack of accuracy and precision. Systematic errors can only be reduced by monitoring and reporting the same parameter by different methods. The sensitivity analysis shows if the monitoring method is consistent between observation and expectation or observation and requirement [22].

There are two important trade-offs concerning uncertainty and reliability of the results: (i) information relevance versus comparability and (ii) cost versus uncertainty [16]. On one hand, one can monitor data, which is only relevant to a certain ship type, but then this data might not be comparable with other types of ships. If the data is comparable, the monitored data might lose relevance. On the other hand, the costs of a MRV system might be high when one desires to reduce uncertainties in the monitoring process to a minimum. This also implies that low-cost monitoring systems are affected by higher levels of uncertainty. According to [16] the principles and concepts of an MRV scheme are often proposed without significant attention to how such schemes are applied in practise in relation with uncertainty. Not many MRV schemes set requirements concerning uncertainty in monitoring and how to deal with them. EU-MRV [17] states that levels of uncertainty correspond with the requirements, national regulations, costumer contracts, and/or fuel suppliers' norms.

Regulations require ships larger than 5,000 GT to take part in MRV; other ships are regarded as less significant for the total emission amount. The monitoring inventory needs to be as complete as possible [18]. The example of relevance in MRV is which sources to include and which not [19]. For instance, the EU-MRV lists the sources of emission on-board for which fuel and emissions must be monitored and reported: main engines, auxiliary engines, boilers, turbines and inert gas generators (for tankers only). Consequently, other emissions sources, such as incinerators, do not necessarily need to be reported. The inventory may be valid without low emitting sources. Assumptions or emission factors might be used to substitute real measured data for low emitting or unknown sources. Non-reliable emission factors or estimated emission factors may increase the uncertainty or errors in the results [23].

\subsection{Confidence / Povjerenje}

General confidence in the program is achieved by making the data publicly available for the sake of transparency. Available data is absolutely required for letting the market do its work to achieve efficiency improvements at the lowest costs. Public data gives access to valuable information to maritime community stakeholders in order to be able to analyse it and invites all actors involved to discuss, alterate and improve the program.

\section{METHODS / Metode}

This paper focuses on the assessment of the existing emissions methodologies inventory and analyses their impact on MRV right implementation on behalf of quality, uncertainty and confidence elements. The applied methodology consisted of a description of eleven existing methods used for making ship emissions inventories including the four methods proposed by EU-MRV. Then, with the data gathered, each method is grouped into (i) Ship Based Methods (SBM) or (ii) Theoretical Based Methods (TBM). SBM focus on the collection of data on board of each individual ship. On the other hand, TBM's emission results are (partly) obtained via modelling, and there is no or a limited amount of data recorded on board. Subsequently, a list of six questions is developed based on the above section theory to assess the usability of these methods for MRV on board:

Q1. Which data is monitored and which required data is assumed?

Q2. How is data collected?

Q3. Which human competency is required?

Q4. How are the trade-offs dealt with in terms of information and costs?

Q5. What are the main uncertainties within the method and how are they dealt with?

Q6. Will the MRV goal be met with the method?

The first two questions are general questions about how and what data is collected. The first five questions are based on [16], which deal with the trade-offs. The last question assesses whether the method can meet the goals from EU-MRV and IMODCS or not. These questions are used in the following section to assess the methods for their MRV relevance and find the method or methods which fit best in MRV application stages.

\subsection{Emission Calculation Methodologies (ECM) inventory / Popis metodologija za izračun emisija}

Eleven existing methods for fuel consumption and emission determination are considered, namely: ENTEC UK Limited [24]; Ship Traffic Emissions Assessment Model and latest versions 
(STEAM) $[25,26]$; methods for estimating shipping emissions in the Netherlands (TNO) [27]; the California Air Resources Board (CARB) method [28]; Use of questionnaires method [29]; On board monitoring devices [30]; Use of Portable Emissions Measurement Systems (PEMS) [31, 32]; Flow meters for applicable combustion processes; Continuous Emissions Measurements (CEM); Bunker fuel tank monitoring [33] and Bunker Fuel Delivery Note (BDN) [34]. All methods are described briefly below:

1. ENTEC UK Limited (TBM): The overall objective of this method is to make preliminary assignments of ship emissions to European countries such as sulphur dioxide $\left(\mathrm{SO}_{2}\right)$, nitrogen oxides $\left(\mathrm{NO}_{x}\right)$, volatile organic compounds (VOCs), particulate matter (PM) and carbon dioxide $\left(\mathrm{CO}_{2}\right)$, for the years 2000, 2010, 2015 and 2020. Seven different methods are applied to assign emissions. The assignment methods to be investigated are a selection of "top-down" and "bottom-up" approaches.

2. Ship Traffic Emissions Assessment Model, STEAM (TBM): This method is presented for the evaluation of exhaust gas emissions of marine traffic, based on the messages provided by the Automatic Identification System (AIS). AIS enables the positioning of ship emissions with high spatial resolution. The model also takes into account the detailed technical data of each individual vessel. The latest update of the model comprises $\mathrm{NO}_{\mathrm{x}^{\prime}} \mathrm{SO}_{\mathrm{x}}$ and $\mathrm{CO}_{2}$ emissions, mass-based emissions of particulate matter (PM) and carbon monoxide (CO). In addition, the model allows for the influence of accurate travel routes and ship speed, engine load, fuel sulphur content, multi-engine set up, abatement methods and the influence of waves. The model includes the total PM emissions and those of organic carbon, elemental carbon, ash and hydrated sulphate. The developers of STEAM have also evaluated the performance of the extended model against available experimental data on engine power, fuel consumptions and the composition-resolved emissions of PM.

3. Methods used by TNO (TBM): This is a method for estimating shipping emissions in the Netherlands by Netherland Organization for Applied Scientific Research (TNO). The study was carried out by TNO as part of the Netherlands Research Program on Particulate Matter (PM) and describes the methods used to estimate PM emissions from shipping, including recently implemented updates for various types of ships. The methods also focus on emission factors and activity data that are currently in use to estimate emissions from berthed ships and from inland and sea shipping.

4. Use of The California Air Resources Board Method, CARB (TBM): $C A R B$ is a survey aimed to investigate the emissions of ships in Californian seaports. The survey targeted the owners or operators of tankers, cruise lines, car carriers, container ships etc. (both domestic and foreign-flagged) that visited California ports in 2006. The purpose of the survey was to gather information to help update the statewide emissions inventory for ocean-going vessels (OGVs), support the development of a proposed regulation to reduce emissions from the operation of OGV main engines and to better understand dockside power needs while loading/unloading in California.

5. Use of questionnaires (TBM): This method uses questionnaires to obtain emission from ships in port, analogue to CARB but from a more generalist point of view. The questionnaire contains questions about general ships characteristics such as ships name, type, volume, year of construction, IMO number (to access more detailed ship data on a later moment). Furthermore, the questionnaire asks for fuel consumption at different stages of shipping: cruising at open sea, manoeuvring towards harbour and while at berth together with duration of stay at berth. Simultaneously, fuel quality and the type of engine and/or machinery in which the fuel is used are requested. The method aims to cover the full spectrum of ship types as well as ships volumes and succeeds rather well at this by covering a wide range of ships volumes for most current ship types.

6. On Board Monitoring Devices, OBMD (SBM): This method is based on the monitoring devices that vessels have on board: Global Positioning System (GPS) and engines fuel consumption meters. The voyage fuel consumption can be calculated in various scenarios of speeds and weather conditions, so the GPS speed data of the ship could approximate the ship's fuel consumption. When the consumption data is combined with measurements of actual speed and position (based on GPS signals) it is possible to directly measure the fuel efficiency. The second device, engines fuel consumption meters, is based on measured fuel flows on board for a specific period. The fuel type and the sulphur content need to be monitored.

7. Use of Portable Emissions Measurement System, PEMS (SBM): Portable Emissions Measurement Systems (PEMS) are essentially lightweight 'laboratories' which are used to test and/or assess mobile source emissions (i.e. ships, cars, trucks, buses, construction equipment, generators, trains, cranes, etc.) for the purposes of compliance, regulation or decision-making. With PEMS it is possible to measure $\mathrm{CO}_{2^{\prime}} \mathrm{NO}_{x^{\prime}} \mathrm{SO}_{x}$ and PM. PEMS are not used for continuous emission measurements.

8. Direct $\mathrm{CO}_{2}$ emissions measurements or Continuous Emission Monitoring, CEM (SBM): Emissions are directly measured at exhaust gas stacks. This method allows for determining the emissions of a ship over a specific period of time. Direct emissions monitoring is thus an approach that can be used for time-based policy measures. A route-based instrument would require a geographic breakdown of the emissions data.

9. Flow meters for applicable combustion processes (SBM): This method is founded on measured fuel flows on board. The data from all flow meters linked to relevant $\mathrm{CO}_{2}$ emission sources can be combined to determine total fuel consumption for a specific period. The period means the time between two port calls or time within a port. For the fuel used during a period, the fuel type and the sulphur content need to be monitored. The calibration methods applied and the uncertainty associated with flow meters used shall be specified in the monitoring plan.

10. Bunker Fuel Tank monitoring on board, BFT (SBM): This method is based on fuel tank readings for all fuel tanks on board. The tank readings shall occur daily when the ship is at sea and each time the ship is bunkering or de-bunkering. The cumulative variations of the fuel tank level between two readings constitute the fuel consumed over the period. Fuel tank readings shall be carried out by appropriate methods such as automated systems, sounding and dip tapes. The method for tank sounding and uncertainty associated shall be specified in the monitoring plan.

11. Bunker Fuel Delivery Note, BDN (SBM): BDN contains information that may be used for the monitoring of fuel consumption in a certain time period and therefore to estimate $\mathrm{CO}_{2}$ emissions. The accuracy of BDN data varies depending on how the fuel quantity stated on the BDN is determined. BDNs have an accuracy level of 1 to $5 \%$ and they can provide an insight into the absolute amount of fuel consumed in a specific period of time when combined with a stock-take at the beginning and at the end of the time period under consideration. This monitoring approach can therefore be used for time-based policy measures and direct incentive for emissions reductions. 


\section{RESULTS / Rezultati}

This section provides the results of the assessment of all the emission calculation methodologies for MRV relevance explained in the above section. The following tables (from Table 2 to Table
7) compare all these methods considering the list of questions formulated in order to enable the choice of one (or more) of them depending on their suitability.

Table 2 Method's assessment based on Question 1

Tablica 2. Procjena metode na temelju 1. pitanja

\begin{tabular}{|c|c|}
\hline Method & Q1. Which data is monitored and which required data is assumed? \\
\hline ENTEC & $\begin{array}{l}\text { Distance sailed; Cruise speed and Power Load factor (Main Engine). Estimated emissions are based on generic assumptions } \\
\text { and average parameter values rather than country specific inputs. }\end{array}$ \\
\hline STEAM & $\begin{array}{l}\text { Data from AIS (location, instantaneous speed); Ship technical data (ship type, ship speed, engine load, fuel sulphur content, } \\
\text { multi-engine set up, abatement method, waves); Propeller power is modelled in terms of speed. All vessels are handled as } \\
\text { single hull and single propeller. Stack data not always available and measured emission factors not always available. There } \\
\text { has been assigned an emission reduction factor to each possible abatement technique. Average values for specific ship type. } \\
\text { Specific fuel oil consumption of } 200 \mathrm{~g} / \mathrm{kWh} \text {. Ship is assumed to use a } 500 \mathrm{rpm} \text { medium speed diesel engine by default. NOx } \\
\text { emission factors based on engine speed and the IMO NO } \mathrm{NO}_{\mathrm{x}} \text { curve. }\end{array}$ \\
\hline TNO & $\begin{array}{l}\text { Ship movement data; Fuel consumption; Fuel type; Emission factors; Engines' year of manufacture; Statistics of freight } \\
\text { transport. Assumption that the ship can maintain the design speed at } 85 \% \text { of the Maximum Continuous Rating (MCR). } \\
\text { Correction factors used for energy consumption and for emission factors. It is assumed that the emission factors of NOx are } \\
85 \% \text { of the IMO limit value for each individual ship. }\end{array}$ \\
\hline CARB & $\begin{array}{l}\text { Ship Information (Name, Date Built, Type, Ship Electrical Power, Gross Tonnage (GT), Net Tonnage (NT), Deadweight (DWT), } \\
\text { average daily fuel consumption at normal cruise speed at sea); Main engine (number, type, date built, fuel used, average } \\
\text { cruise power at sea, average cruise speed at sea, engine modifications completed to either improve fuel efficiency or } \\
\text { reduce emissions), Auxiliary engines (make, model, date built, rated power at MCR, type, fuel type used within } 24 \text { nautical } \\
\text { miles of baseline), average total ship power generated from engines (at sea, manoeuvring and hoteling); potential vessel } \\
\text { modifications for using marine distillate fuels. No data assumed. If not available, not included. }\end{array}$ \\
\hline Questionnaire & $\begin{array}{l}\text { Type of ship, GT or length; Ships name, type, volume, year of build, IMO number; fuel consumption at different stages of } \\
\text { shipping: cruising at open sea, manoeuvring towards harbour and while at berth together with duration of stay; fuel quality } \\
\text { and the type of engine and/or machinery. }\end{array}$ \\
\hline OBMD & Speed and position of vessel; Fuel consumption; Fuel type; Fuel sulphur content \\
\hline PEMS & Emissions. \\
\hline CEM & Emissions. \\
\hline Flow-meters & Fuel consumption. \\
\hline BFT & Fuel level tanks; fuel type; fuel sulphur content. \\
\hline BDN & Amount of fuel loaded on board. \\
\hline
\end{tabular}

Table 3 Method's assessment based on Question 2

Tablica 3. Procjena metode na temelju 2. pitanja

\begin{tabular}{|c|c|}
\hline Method & Q2. How is data collected? \\
\hline ENTEC & $\begin{array}{l}\text { Lloyds Maritime Intelligence Unit (LMIU) database. Ship movements database, in combination with the Lloyd's Maritime } \\
\text { Information System (LMIS). Vessel characteristics database. }\end{array}$ \\
\hline STEAM & $\begin{array}{l}\text { Lloyd's Ship Register Database data with manufacturer information, local authorities and ship owners offer a database for } \\
\text { more than } 20.000 \text { vessels. }\end{array}$ \\
\hline TNO & $\begin{array}{l}\text { Technical data from the Lloyd's register of shipping information and AIS. IHS Maritime World Register of Ships database. } \\
\text { Emission factors per amount of energy were derived by [35]. }\end{array}$ \\
\hline CARB & By means of a survey filled in on board vessels. \\
\hline Questionnaire & $\begin{array}{l}\text { Surveyors went on board together with harbours ships safety inspectors on } 89 \text { ships in the Port of Rotterdam. Emission } \\
\text { factors per amount of energy were derived by [35]. Activity data from Statistics Netherlands (2007) }\end{array}$ \\
\hline OBMD & Depending on type of equipment, but used to measure energy related parameters. \\
\hline PEMS & Portable emissions measurement device, mostly installed at the funnel stack. \\
\hline CEM & Emissions measurement device installed somewhere in ship funnel. \\
\hline Flow-meters & Measuring fuel flow directly or indirectly. Monitoring all entries of fuel consumers. \\
\hline BFT & Readings of fuel tanks on board. \\
\hline BDN & BDN notes. Oil record book. \\
\hline
\end{tabular}

Table 4 Method's assessment based on Question 3

Tablica 4. Procjena metode na temelju 3. pitanja

\begin{tabular}{|c|c|}
\hline Method & Q3. Which human competency is required? \\
\hline ENTEC & Operators basic competence for comparing modelling outputs with real data. \\
\hline STEAM & $\begin{array}{l}\text { Operators basic competence for comparing modelling outputs with real data. This is a theoretical computational } \\
\text { methodology, therefore, no need for human competency on board. Need for investment, as private company carries out } \\
\text { the study. Cost unknown. }\end{array}$ \\
\hline \multirow{2}{*}{$\begin{array}{l}\text { TNO } \\
\text { CARB }\end{array}$} & Operators basic competence for comparing modelling outputs with real data. \\
\hline & The data is collected on board by engineers. Therefore, operators' competence required. \\
\hline \multirow{4}{*}{$\begin{array}{l}\text { Questionnaire } \\
\text { OBMD } \\
\text { PEMS } \\
\text { CEM }\end{array}$} & The data is collected on board by engineers, therefore, operators' competence required. \\
\hline & Experienced operators: operator competence is required. Training on operation and calibration device. \\
\hline & Experienced operators: operator competence is required.Training on operation and calibration device. \\
\hline & Experienced operators: operator competence is required. Training on operation and calibration device. \\
\hline \multirow{3}{*}{$\begin{array}{l}\text { Flow-meters } \\
\text { BFT } \\
\text { BDN }\end{array}$} & Experienced operators: operator competence is required. Training on operation and calibration device. \\
\hline & Experienced operators: operator basic competence is required. \\
\hline & Experienced operators: operator basic competence is required. \\
\hline
\end{tabular}


Table 5 Method's assessment based on Question 4

Tablica 5. Procjena metode na temelju 4. pitanja

\begin{tabular}{|c|c|}
\hline Method & Q4. How are the trade-offs dealt with in terms of information and costs? \\
\hline ENTEC & $\begin{array}{l}\text { The model includes many stages and, during the stages, information is gathered. At first glance the method tries to be as } \\
\text { complete as possible by combining other methods. The effort in time for the collection of data, emission calculation and } \\
\text { evaluation of the results are the main costs. }\end{array}$ \\
\hline STEAM & $\begin{array}{l}\text { An inclusive method which takes many parameters into account. The model also tries to be as complete as possible. The } \\
\text { collection of data and following steps are assumed to take some effort and are thus costly. }\end{array}$ \\
\hline TNO & $\begin{array}{l}\text { A method with a high assumption rate to present a certain order of magnitude of PM emissions. Only collection of basic data } \\
\text { required. Not assumed to be very costly. }\end{array}$ \\
\hline CARB & $\begin{array}{l}\text { Results are subtracted from survey information which is held on board. The aim of the method is clearly defined and not } \\
\text { extensive. The collection during the survey takes some time and it is the stage in the method with the highest costs. However } \\
\text { it is not assumed to be very high. }\end{array}$ \\
\hline Questionnaire & $\begin{array}{l}\text { A simpler approach to determine ship emissions, due to a lack of essential technical data. Elemental parameters have to be } \\
\text { assumed. The method tries to be complete, but some results may present an order of magnitude due the assumptions that } \\
\text { have been made. It takes some effort to collect the data by the questionnaire and the modelling takes some time as well. }\end{array}$ \\
\hline OBMD & $\begin{array}{l}\text { Information and costs depend on the aim of which the devices are used for. Require investment, running, and maintenance } \\
\text { costs. Costs will be higher when using more monitoring devices. }\end{array}$ \\
\hline PEMS & $\begin{array}{l}\text { The price can vary greatly depending on the quality and accuracy of the device. Application of the device needs to be done } \\
\text { according to the prescribed standards and it may cost some time. }\end{array}$ \\
\hline CEM & $\begin{array}{l}\text { Requires investment and running costs; requires higher maintenance. Price can vary greatly depending on the quality and } \\
\text { accuracy of the devices. }\end{array}$ \\
\hline Flow-meters & $\begin{array}{l}\text { Costs depend on the method of measuring. Flow meters have specific aim and not much data input is required and } \\
\text { straightforward output. Meters need maintenance. Data reporting costs/burden modest if automatically monitored. }\end{array}$ \\
\hline BFT & $\begin{array}{l}\text { Simple and straightforward method resulting in basic information. Costs depend on the method of measuring. Bunker tank } \\
\text { soundings do not burden the crew excessively. }\end{array}$ \\
\hline BDN & Basic information. No equipment costs and no running costs. \\
\hline & $\begin{array}{l}\text { Table } 6 \text { Method's assessment based on Question } 5 \\
\text { Tablica 6. Procjena metode na temelju 5. pitanja }\end{array}$ \\
\hline Method & Q5. What are the main uncertainties within the method and how are they dealt with? \\
\hline ENTEC & $\begin{array}{l}\text { Based on the derived function and the estimated uncertainties of the input parameters the uncertainty of the preliminary } \\
\text { emission results is estimated. Depending on the methodologies proposed by ENTEC, uncertainties range is from } 10 \text { to } 42 \% \text {. }\end{array}$ \\
\hline STEAM & $\begin{array}{l}\text { Significant uncertainties exist in determining the time spent at sea, engine load profiles used and emission factors applied. } \\
\text { Uncertainties regarding the chemical composition and other properties of the emitted PM. Uncertainties regarding } \\
\text { the emission factors of } \mathrm{NO}_{\mathrm{x}} \text {. The change of emission factor due to engine load is not taken into account. Uncertainties } \\
\text { concerning the predicted power of the auxiliary engines, which significantly affect the emissions in port areas. The way to } \\
\text { deal with these uncertainties is getting as much data as possible. }\end{array}$ \\
\hline TNO & $\begin{array}{l}\text { A theoretical calculation method based on AIS and LR Data. There are some assumptions made. } \\
\text { The information relevance is not sensitive as there is no fuel consumption rate shared and it is applicable to any type of } \\
\text { vessel as long as technical data is available. Uncertainty estimates for greenhouse gas emissions have been quantified in } \\
\text { referenced report. Due to a lack of technical data, emissions are presented as a function of gross tonnage instead of using } \\
\text { the more accurate g/kWh. The former is namely a linear relation and does not take into account the economy of scale. } \\
\text { Depending on methodology used (Tier) and compound analysed, uncertainties could go from } 3 \% \text { up to } 50 \% \text {. }\end{array}$ \\
\hline CARB & $\begin{array}{l}\text { Emissions calculation method is not explained. All requested information was given and was kept confidential; data can be } \\
\text { compared but not for all types of vessels. }\end{array}$ \\
\hline Questionnaire & $\begin{array}{l}\text { All requested information was given and kept confidential; data can be compared but not for all types of vessels. Uncertainty } \\
\text { is high in some cases. Correlation coefficients are rather low and the variability in the outcome was rather large. For three } \\
\text { ship types the correlation is poor (Container ships, General Cargo and "Other"). }\end{array}$ \\
\hline OBMD & Depending on way of measuring. \\
\hline PEMS & $\begin{array}{l}\text { It is often difficult for PEMS to offer the same accuracy and variety of species measured as it is possible with top of the line } \\
\text { laboratory instrumentation. The uncertainties depend on the quality and accuracy of the device. }\end{array}$ \\
\hline CEM & Uncertainties range is $+/-2 \%$ \\
\hline Flow-meters & Highest potential accuracy. \\
\hline BFT & $\begin{array}{l}\text { Sensitive to inaccuracies as it relies only on fuel tank readings. Discrepancies between the tank volume calculated and the } \\
\text { actual volume consumed due to on board fuel treatment processes. }\end{array}$ \\
\hline BDN & Uncertainties range is from 1 to $5 \%$. They vary depending on how the fuel quantity is determined. \\
\hline
\end{tabular}


Table 7 Method's assessment based on Question 6

Tablica 7. Procjena metode na temelju 6. pitanja

\begin{tabular}{|c|c|}
\hline Method & Q6. Will the MRV goal be met with the method? \\
\hline ENTEC & $\begin{array}{l}\text { It doesn't meet all MRV goals, but it is suitable for estimating emissions and for using the method outputs afterwards in the } \\
\text { verification phase comparing real values with modelling outputs. } \\
\text { The method does not neither include the direct measurement of gas concentration nor the record of proxies (such as fuel } \\
\text { consumption). }\end{array}$ \\
\hline STEAM & $\begin{array}{l}\text { Taking into account that accuracy in terms of fuel consumption is } 6 \% \text {, when comparing results from STEAM theoretical } \\
\text { approach to information given by ship owners, it could be concluded that this approach could be used for emissions } \\
\text { estimation, provided all requested data were available. Furthermore, method outputs could be compared with real values } \\
\text { in MRV verification phase. }\end{array}$ \\
\hline TNO & $\begin{array}{l}\text { As this methodology does not include the direct measurement of gas concentration neither the record of proxies, it might } \\
\text { not meet all MRV goals but it is a good method for estimating emissions and for using the method outputs afterwards in } \\
\text { the verification phase comparing real values with modelling outputs. }\end{array}$ \\
\hline CARB & $\begin{array}{l}\text { For monitoring in Californian ports it could be useful but not for all type of vessels. Only container ships, bulk carriers, } \\
\text { tankers and cruise ships as they are ocean going vessels. Harbour craft such as ferries, fishing vessels and tug/tow boats, } \\
\text { not applicable. }\end{array}$ \\
\hline Questionnaire & Useful for determining emissions in ports. \\
\hline OBMD & Yes \\
\hline PEMS & Yes \\
\hline CEM & Yes \\
\hline Flow-meters & Yes \\
\hline BFT & Yes \\
\hline BDN & Yes \\
\hline
\end{tabular}

The first five methods are Theoretical Based Methods (TBM) and the last six are Ship Based Methods (SBM). As it arises from above tables, some TBM methods do not comply with the monitoring phase of MRV as they take the technical data for emissions calculation from databases (such as Lloyd Register) and not from real-time variables measured on board. Nevertheless, the assessment also shows that some TBM's could be feasible as alternative methods when using questionnaires to extract activity data from ships. Approaches such as STEAM or CARB are excellent methods to verify the monitoring phase. In addition, some TBM might be used for verification in terms of comparing the results obtained from the data recorded on board with modelling outputs. For instance, ENTEC and STEAM are based on ship movement information for individual ships instead of generalising as per ship type or Gross Tonnage range. STEAM verifies ship emissions by modelling the ship's work based on AIS, technical data and real-time weather and sea conditions. Furthermore, it also considers the nowadays existing emission abatement techniques. In terms of the importance of the waves for individual ships, the estimated increase of hourly fuel consumption could be between 10-20\% [25]. Further hourly averaged and voyage specific fuel consumption data is needed to draw more detailed conclusions regarding the significance of the effect of waves. On a local scale or for individual ships, the effect of waves is not necessarily negligible. Furthermore, STEAM points out for being the method with most realistic outputs when comparing them to real data. Much of the uncertainty of the TBM methodologies in the activity data for shipping emission estimates is related to the difficulty of distinguishing between national and international fuel consumption (from $\pm 5 \%$ to $\pm 50 \%$ ). Reporting is expected to improve the global data sets which may be helpful in this area as stated by ENTEC. On the other hand, SBM methods seem to be the most appropriates to comply with MRV specifications. Even though, there are some nuances to take into consideration. The SBM which use on board monitoring equipment are feasible when the output is considered. The potential of these methods lies on the monitoring process used. Firstly, one can monitor the fuel consumption and carbon content of the exhaust gasses; the basic approach to comply with regulations. Secondly, ships can monitor other additional (relevant energy) processes or proxies by implementing more measuring and monitoring equipment. Accordingly, more processes can be followed. In addition, when taking into account SBM as BDN, for instance, it is widely known that there exists some reluctance to divulge this information to a third party. Furthermore, when focusing on board monitoring devices or fuel meters, all recirculated fuel should be taken into account. When talking about PEMS or CEM, besides the costs implied, there has to be a system installed on every stack, the system must be continuously working, all monitored data correctly documented and reported, the equipment requires frequent calibration and this has to be done by experienced operators. Aforementioned statements mean more investment. SBM could give realistic values on emissions depending on the methodology analysed, as for PEMS or CEM, for instance. However, these 2 methodologies will not mandatorily discriminate the source neither. It would be desirable to mount an independent flow meter for each fuel consumer in order to be able to discriminate the consumption and to obtain distinctive and reliable emissions data.

\section{DISCUSSION / Rasprava}

The shipping industry has practically no other choice than to implement MRV on board because the measures are already ratified and legally binding. It is important that the companies define, in the monitoring plan, which monitoring methodology is used to calculate fuel consumption for each ship type under its responsibility and must ensure that once it has been chosen, is consistently applied. However, some aspects of MRV can be problematic and the success of best practices depends on how the shipping industry perceives MRV on board their ships. Their main issues are qualitatively summed up as follows:

1. The data that needs to be collected is rather sensitive and needs to be treated as confidential. The results may 
affect the economic or legal position of ship owners [36]. Additionally, there is the problem of who is responsible for the fuel consumption and resulting emissions in time charters. The charterer of a vessel is responsible for the fuel input (supply and payments) during time charters and the charterer might be the party who has the primary MRV responsibility [37].

2. The shipping industry demanded anonymity of their data in the future MRV schemes during negotiations for the new MRV legislation. In IMO-DCS, anonymity is ensured in the assessment of the submitted data. The discussion of anonymity generates tension between public interest and economical interest.

3. Uncertainty about the way of monitoring: which parameters need to be measured and which data is required, and how, what to do with the data, what to say about the quality of the data and what about the extra costs? [15]

4. A major issue is the difference between EU-MRV and IMODCS (see Table 1). Ships have to comply with both schemes but they demand different input and different administrative management [38], which in view of the shipping industry needs extra work to reach the same goal in two ways. This situation hampers the idea of 'low extra administrative burden' and is most probably not supportive for the three issues above.

5. An important issue would be the amount of different pollutants emitted into the atmosphere and this could be analysed by the methodologies proposed. Nevertheless, when talking in terms of emissions mitigation, distinctive data should be obtained in order to apply correct procedures for each consumer.

Based on the above explanation, the arguments are mostly practical; paraphrased as: what do we need to do and what are our gains? This study does not answer these questions directly, but hopes to present a different point of view, so that the industry picks up the gauntlet and starts to develop its so-needed best practices. The methods - especially STEAM could be used in the verification process analogue to the ATC verification in aviation, because of the use of AIS data. [39] verified the results from IMO's Third GHG Study [2] with aid of the STEAM approach and both results agreed. But what would happen if an approach like the one used in STEAM is used the other way around, so that the monitoring is performed via modelling? Monitoring is shifted from ship to shore and ship owners only have to verify the results. Starting with such a way of monitoring would be the development of a best practise without the direct involvement of the shipping industry. A third party scrutinizes the movements of the vehicles and calculates the emissions. If the results are in a same order of magnitude, the modelling results will be published and available to the market. Data about fuel consumption and emissions will be collected without direct efforts of ship operators. [39] argue that the STEAM models are quite suitable to "analyse emission results in a detailed and versatile manner" and can perfectly be used on smaller scale, because the model is applicable onto individual ship level.

\section{CONCLUSION / Zaključak}

Current maritime business practices do not permit the right implementation of Monitoring, Reporting and Verification. Best practices are required as knowledge base for a complete and correct application of MRV. However, best practices can only be developed after a certain time of experience and ships have to comply with the European Union (EU-MRV) and the International Maritime Organization (IMO-DCS) regulations. A solution could be the application of existing theoretical approaches which are able to determine ship emissions on individual ship level. This research is one of the first attempts to evaluate the existing emission calculation methods to be used for energy and emission monitoring on board ships and could be useful for the maritime business. Eleven existing methods have been assessed by a set of MRV related questions based on key MRV elements (quality, uncertainty and confidence) found in literature. Methods have been classified as Theoretical Based Methods (TBM) and Ship Based Methods (SBM). When taking a look into TBM it could be concluded that these methodologies are more generalist. Most of the TBM offer the possibility to calculate emissions from the values of the emission factors published. Others, as STEAM, give the possibility to calculate the emission factors theoretically based on the fuel portion of Carbon and Sulphur or based on IMO regulations for NOx. Taking this information into account, the theoretical emissions could be calculated as far as the fuel consumption is known but this will not discriminate among different sources of emissions unless fuel consumption data for each engine or boiler on board is available. TBM methods may not comply with the monitoring phase of MRV but could be feasible as alternative method when using real-time data to extract activity data from ships. Moreover, some TBM methods might be used for verification in terms of comparing the results obtained from the data recorded on board with modelling outputs (for instance ENTEC and STEAM). The STEAM method determines ship emissions by modelling the ship's work based on AIS, technical data and real-time weather and sea conditions, while it also considers abatement techniques. Therefore, STEAM points out as being the methodology with the most realistic outputs when comparing with real data. STEAM could be suitable to use as a different approach for MRV, but this method has not been tested as early best practices. On the other hand, SBM methods seem to be the most appropriates to comply with MRV specifications. Nevertheless, some of the SBM methods require more investment. In this contribution, a different approach is presented and existing methods could be applicable as early best practices on Monitoring, Verification and Reporting emissions on board.

\section{ACKNOWLEDGEMENTS / Zahvala}

The materials and data in this publication have been obtained through the support of the International Association of Maritime Universities (IAMU) and The Nippon Foundation in Japan.

\section{REFERENCES / Literatura}

[1] Omer N., Comer B., Roy B., Mao X. and Rutherford D. (2017) Greenhouse gas emissions from global shipping, 2013-2015. International Council on Clean Transportation

[2] International Maritime Organization, IMO. (2015) Third IMO greenhouse gas study 2014. International Maritime Organization, London https://doi org/10.1787/9789264244047-34-en

[3] Leaper R., Renilson M., Ryan C. (2014) Reducing underwater noise from large commercial ships: Current status and future directions. J OCEAN TECHNOL 9(1): 51-69

[4] Psaraftis H.N., Kontovas C.A. (2013) Speed models for energy-efficient maritime transportation: A taxonomy and survey. TRANSPORT RES C-EMER 26:331-351. https://doi.org/10.1016/j.trc.2012.09.012

[5] De Simio L., Gambino M., lannaccone S. (2013) Possible transport energy sources for the future. TRANSPORT POLICY 27(0):1-10. https://doi. org/10.1016/j.tranpol.2013.01.006 
[6] Armstrong V.N. (2013) Vessel optimisation for low carbon shipping. OCEAN ENG 73:195-207. https://doi.org/10.1016/j.oceaneng.2013.06.018

[7] Vergara J., McKesson C., Walczak M. (2012) Sustainable energy for the marine sector. ENERG POLICY 49(0):333-345. https://doi.org/10.1016/j. enpol.2012.06.026

[8] Jurić T., Radica G., Jelić M. (2016) Experimental Method for Marine Engine's Emissions Analysis. Naše more, International Journal of Maritime Science and Technology 63(1): 24-31. https://doi.org/10.17818/nm/2016/1.4

[9] International Maritime Organization. (2012) EEDI - rational, safe and effective. http://www.imo.org/en/MediaCentre/HotTopics/. Accessed 3 August 2017

[10] Poulsen R.T., Johnson H. (2016) The logic of business vs. the logic of energy management practice: Understanding the choices and effects of energy consumption monitoring systems in shipping companies. J CLEAN PROD 112(5):3785-3797. https://doi.org/10.1016/j.jclepro.2015.08.032

[11] Jafarzadeh S., Utne I.B. (2014) A framework to bridge the energy efficiency gap in shipping. ENERGY 69:603-612. https://doi.org/10.1016/j. energy.2014.03.056

[12] Johnson H., Johansson M., Andersson K. (2014) Barriers to improving energy efficiency in short sea shipping: An action research case study. J CLEAN PROD 66:317-327. https://doi.org/10.1016/j.jclepro.2013.10.046

[13] Lai K.H., Lun V.Y.H., Wong C.W.Y., Cheng T.C.E. (2011) Green shipping practices in the shipping industry: Conceptualization, adoption, and implications. RESOUR CONSERV RECY 55(6):631-638. https://doi. org/10.1016/j.resconrec.2010.12.004

[14] Poulsen R.T., Sornn-Friese H. (2015) Achieving energy efficient ship operations under third party management: How do ship management models influence energy efficiency? Research in Transportation Business \& Management 17:41-52. https://doi.org/10.1016/j.rtbm.2015.10.001

[15] Scott J., Smith T., Rehmatulla N., Milligan B. (2017) The promise and limits of private standards in reducing greenhouse gas emissions from shipping. J ENVIRON LAW 29:231-262. https://doi.org/10.1093/jel/eqw033

[16] Ballassen V., Stephan N., Afriat M., Alberola E., Barker A., Chang J. (2015) Monitoring, reporting and verifying emissions in the climate economy. NAT CLIM CHANGE 5:319- 328. https://doi.org/10.1038/nclimate2544

[17] European Union. (2015) Regulation 2015/757 of the European Parliament and of the European Council on the Monitoring, Reporting and Verification of Carbon Dioxide Emissions from Maritime Transport, and amending Directive 2009/16/EC. European Union, Brussels

[18] International Maritime Organization, IMO. (2016) Data collection system for fuel oil consumption of ships. Retrieved from http://www.imo.org/ en/OurWork/Environment/PollutionPrevention/AirPollution/Pages/DataCollection-System.aspx. Accessed 2 August 2017

[19] Schakenbach J., Vollaro R., Forte R. (2006) Fundamentals of successful monitoring, reporting, and verification under a cap-and-trade program. J AIR WASTE MANAGE 56:1576-1583. https://doi.org/10.1080/10473289.200 6.10464565

[20] Kitada M., Ölçer A. (2015) Managing people and technology: The challenges in CSR and energy efficient shipping. Research in Transportation Business \& Management 17:36-40. https://doi.org/10.1016/j.rtbm.2015.10.002

[21] Johnson H., Anderson K. (2014) Barriers to energy efficiency in shipping WMU J Marit Affairs 15:79-96. https://doi.org/10.1007/s13437-014-0071-z

[22] Jenkins C., Chadwick A., Hovorka S.D. (2015) The state of the art monitoring and verification - ten years on. INT J GREENH GAS CON 40:312-349. https:// doi.org/10.1016/j.ijggc.2015.05.009

[23] Nunes R., Alvim-Ferraz M., Martins F., Sousa S. (2017) The activity-based methodology to assess ship emissions - A review. ENVIRON POLLUT 231:87103. https://doi.org/10.1016/j.envpol.2017.07.099
[24] Entec UK Limited (2005) Service Contract on Ship missions: Assignment, Abatement and Market-based Instruments Task 2c - SO2. European Commission Directorate General Environment Abatement - Final Report

[25] Jalkanen J.P., Brink A., Kalli J., Pettersson H., Kukkonen J. and Stipa T. (2009) A modelling system for the exhaust emissions of marine traffic and its application in the Baltic Sea area. ATMOS CHEM PHYS 9: 9209-9223. https:// doi.org/10.5194/acp-9-9209-2009

[26] Jalkanen J.P., Johansson L., Kukkonen J., Brink A., Kalli J. and Stipa T. (2012) Extension of an assessment model of ship traffic exhaust emissions for particulate matter and carbon monoxide. ATMOS CHEM PHYS 12: 2641 2659. https://doi.org/10.5194/acp-12-2641-2012

[27] Denier van der Gon H.A.C., Hulskotte J. (2010) Methodologies for estimating shipping emissions in the Netherlands- A documentation of currently used emission factors and data on related activity. Netherlands Environmental Assessment Agency - Report 500099012, Netherlands Research Program on Particulate Matter

[28] California Environmental Protection Agency. (2007) 2007 Ocean-Going Ship Survey, Appendix C. Stationary Source Division Emissions Assessment Branch

[29] Hulskotte J., Denier van der Gon H. (2010) Fuel consumption and associated emissions from seagoing ships at berth derived from an on-board survey. Atmospheric Environment 44: 1229-1236. https://doi.org/10.1016/j. atmosenv.2009.10.018

[30] European Union, EU. (2015) Regulation 2015/757 of the European Parliament and of the European Council on the Monitoring, Reporting and Verification of Carbon Dioxide Emissions from Maritime Transport, and amending Directive 2009/16/EC. European Union, Brussels. https://doi. org/10.5771/9783845271873-1078

[31] Kousoulidou M. et al. (2013) Use of portable emissions measurement system (PEMS) for the development and validation of passenger car emission factors. ATMOS ENVIRON 64:329-338. https://doi.org/10.1016/j. atmosenv.2012.09.062

[32] Maldonado H. (2006) Evaluation of Portable Emission Measurement Systems (PEMS) for Inventory Purposes and the Not-To-Exceed Heavy Duty Diesel Engine Regulation. Report, Research Division California Air Resources Board

[33] Lloyd's Register. (2014) European Union regulation and monitoring, reporting and verification of carbon dioxide from ships, in final legislative stages. (Executive Summary)

[34] Faber J., Nelissen D., Smit M. (2013) Monitoring of bunker fuel consumption. CE Delft, Delft

[35] Oonk H. et al. (2003) Emission Factors of Seagoing Ships on the Purpose of Yearly Emission Calculation (in Dutch). TNO-report R 2003/438 version 2

[36] Rahim M.M., Islam T., Kuruppu S. (2016) Regulating global shipping corporations' accountability for reducing greenhouse gas emissions in the seas. MAR POLICY 69:159-170. https://doi.org/10.1016/j.marpol.2016.04.018

[37] Stopford M. (2009) Maritime Economics. Routledge: London

[38] IMarEST. (2017) Response from IMarEST members on revision of EU MRV regulation on $\mathrm{CO} 2$ emissions from maritime transport. Retrieved from https://www.imarest.org/policy-news/technical-leadership/item/3871 response-from-imarest-members-on-revision-of-eu-mrv-regulation-onco2-emissions-from-maritime-transport, accessed 4 September 2018. https://doi.org/10.1787/888933442558

[39] Johansson L., Jalkanen J.P., Kukkonen J. (2017) Global assessment of shipping emissions in 2015 on a high spatial and temporal resolution. ATMOS ENVIRON 167:403-415. https://doi.org/10.1016/j.atmosenv.2017.08.042 